\title{
The Pepermint Based Method on Anti-Pornography Community Program At SMPN 3 Banjarbaru
}

\author{
Aulia Ulfa ${ }^{1}$, Gina Chairina Jahrah ${ }^{1}$, Eva Mujiarahmah ${ }^{1}$, Fauzie Rahman ${ }^{2}$, \\ \{auliaulfa0112@gmail.com¹, fauzie21@ulm.ac.id²\} \\ College Student of Public Health, Faculty of Medicine, Lambung Mangkurat University, Banjarbaru, \\ Indonesia ${ }^{1}$, \\ Department of Health Policy Administration, Public Health, Faculty of Medicine, Lambung \\ Mangkurat University, Banjarbaru, Indonesia ${ }^{2}$
}

\begin{abstract}
Pornography can cause damage to the five parts of the brain, especially in the pre frontal corteks. Damage to parts of the brain will make academic achievement decline, unable to make plans, control the passions and emotions, make decisions, and a variety of executive roles of the brain as controlling impulses. Anti-Pornography Community Program Method Based Peer Educator, Peer Counselor and Motivational Interviewing (Pepermint) SMPN 3 Banjarbaru is a form of innovation of the methods of counseling and education related to adolescent reproductive health problems, especially by focusing on preventive interventions pornography addiction in adolescents. Evaluation is done by measuring students' knowledge and attitudes before and after the carried out activities. Based on analysis reveals the p-value $=0.000(\alpha=0.05)$. This means that there are differences in students' knowledge before and after the activity. Efforts to further development and community empowerment peppermint counselors to students to prevent and address the problems of pornography and adolescent reproductive health that occurs, monitoring and evaluation of peppermint counselor who became the first pioneers in this activity
\end{abstract}

Keywords: Pornography, community, peer, teens.

\section{Introduction}

The development of technology and information currently impacting on the ease of internet access for adults to children. The positive impacts arising from the development of the internet in Indonesia is the ease of communicating and searching for information for the public, but the negative side for the individual and the group, namely loss of material, mental and even to the death. The negative side of internet usage among others are cyberbullying, cybercrime, cyberstalking, gambling, pornography, online fraud and others [1].

Pornography is one of the problems highlighted the government in Indonesia, especially the Ministry of Communications and Information Technology. Blocking or filter method, and also called on the telecommunications companies and internet service providers are obliged to block web sites that contain pornographic content. But these efforts have not overcome the problem of pornography in their entirety. The program gaps have a negative impact and will influence the attitudes and behavior of adolescents in heterosexual relationships or dating to sexual behavior, either in the form of handrails, embracing, necking to sexual intercourse [2][3]. 
The law in Indonesia (Undang-Undang Number 44 Year 2008) about pornography has long been published but factually pornographic content is still growing rapidly. Pornography is easily found in the form of drawings, sketches, illustrations, photographs, text (message), voice, sound, moving pictures, animation, cartoons, conversation, gesture pass through various media communication and the show in public place that contain sex exploitation element which break morality norm [4].

The Ministry of Communications and Information Technology said that from the data one of child protection organization known as much as $97 \%$ of the 4,500 adolescents and secondary school ever access porn sites through internet cafes and also pornographic videos in the form of VCDs are sold freely in market [5]. According to the study results in the Journal of Sexual Medicine Online, there are 3 types of pornography users, ie users with recreational purposes, compulsive users, and users who are depressed. Prevention and treatment of child pornography users should be implemented since early [4].

One of method that can be performed is using the method of pepermint, that is peer educator, peer counselors, as well as the motivational interviewing. The first method, peer educator discusses the counseling, information and education conducted by peer and to the peer, to train adolescents become adolescent health counselors and peer educators will act as an agent of change [6]. The second method, peer counselors to conduct debriefing with the participants, resulting in the expected two-way communication that respondents understand the intention of the counselor [7]. The third method, motivational interviewing push explore, and find the reason of them that they had never thought to change the behaviour [8]. So this program is implemented by the election and the formation of a counselor who will focus on counseling and education of their peer. After that, the counselors will be get training and they will make a community antipornography which will grow up the behaviour and attitude prevent pornography and increase the knowledge of teenagers about reproduction health.

Counselors as one of the elements that contribute to the development of education student morale. Technological developments should be a medium capable of building morale of students to a better direction. Some roles do school counselors to anticipate the emergence of a moral crisis in children and adolescents is; 1) increase the ability and skills to take advantage of the presence of "new media", 2) in cooperation with the homeroom teacher and parents to monitor the use of new media, in the form of frequency, duration and content, 3) Educating internet use positive, 4) learn strategies counseling to deal with problems that arise among them, addicted to online games, pornography, bullying and hate speech [9]. The experience of teenagers in peer group really useful to achieve independent attitude and maturity interpersonal relation [10].

Application of the method of peer is expected to have a positive impact rising toward result of their learning because students feel free to express their opinions with their peer and they do not feel shy and unwilling [11]. Therefore, the task of the social development of young people in the peer group must be controlled to the optimum. The developmental task achievement optimization can be achieved by organizing various types of guidance and counseling [10]. Therefore, there should be elections counselor at the school that will serve as a good role model for behavior.

There are many community-based service agencies, but experienced a problem of human resources, financial services and even infrastructure. Impact, rampant violations of child victims in various regions point less gain komprehensif settlement services [12]. Therefore, it is necessary to have existence of program anti-pornography community can reach children and adolescents for prevention and mitigation of the impact of pornography. 


\section{Method}

This study was a quantitative study with a crossectional approach. The study was conducted in SMPN 3 Banjarbaru, located in Cempaka District, Banjarbaru in April-May 2019. Activities at SMPN 3 Banjarbaru executed in 5 classes with two different times. This activity consists of two materials, namely on adolescent reproductive health and pornography. The number of participants who follow these events amounted to 123 people who come from class VII-A. VII-B, VII-C, VII-E dan VII-F representative. Pre-post test performed in order to measure changes in knowledge, done before the election activities counselor begins, with the division of two different materials, namely on adolescent reproductive health and pornography.

Data collection was done through questionnaires with respondents. The questionnaire contain two different materials, namely on adolescent reproductive health and pornography. To see an overview of the main characteristics and independent variables, univariate analysis of categorical data was carried out by presenting numbers and percentages. The analysis used to determine the average difference before and after intervention is performed by Paired t test (Dependent T-Test) if the normal distribution and Wilcoxon test if it does not meet for the paired $t$ test. Variable knowledge before and after the intervention is not normal because of significant $(0.000)<0.05$. The results of the analysis using the Wilcoxon test with the hypothesis:

$\mathrm{H} 0: \mathrm{d}=0$ (no difference in knowledge of the student before and after the event).

$\mathrm{H} 1: \mathrm{d} \neq 0$ (there is a difference of student knowledge before and after the event).

\section{Result}

Table 1. shows an overview of knowledge before and after education that given in different 5 class. The respondents were teenager around teenagers around the age of 12-13 years in 7 th grade.

Tabel 1. Distribution and frequency of knowledge before and after education is given at SMPN 3 Banjarbaru

\begin{tabular}{|c|c|c|c|c|c|c|c|c|}
\hline \multirow{3}{*}{$\begin{array}{c}\text { The Stage } \\
\text { of } \\
\text { Knowledge }\end{array}$} & \multicolumn{4}{|c|}{ First Class } & \multicolumn{4}{|c|}{ Second Class } \\
\hline & \multicolumn{2}{|c|}{$\begin{array}{c}\text { Adolescent } \\
\text { Reproductive } \\
\text { Health }\end{array}$} & \multicolumn{2}{|c|}{ Pornography } & \multicolumn{2}{|c|}{$\begin{array}{c}\text { Adolescent } \\
\text { Reproductive } \\
\text { Health }\end{array}$} & \multicolumn{2}{|c|}{ Pornography } \\
\hline & $\begin{array}{l}\text { Pre- } \\
\text { test }\end{array}$ & $\begin{array}{c}\text { Post- } \\
\text { test }\end{array}$ & $\begin{array}{l}\text { Pre- } \\
\text { test }\end{array}$ & $\begin{array}{c}\text { Post- } \\
\text { test }\end{array}$ & $\begin{array}{l}\text { Pre- } \\
\text { test }\end{array}$ & $\begin{array}{c}\text { Post- } \\
\text { test }\end{array}$ & $\begin{array}{l}\text { Pre- } \\
\text { test }\end{array}$ & $\begin{array}{c}\text { Post- } \\
\text { test }\end{array}$ \\
\hline Very good & $3(5.9 \%)$ & $\begin{array}{l}31 \\
(60.8 \%)\end{array}$ & $2(3.9 \%)$ & $\begin{array}{l}8 \\
(15.7 \%)\end{array}$ & $3(4.2 \%)$ & $\begin{array}{l}23 \\
(31.9 \%)\end{array}$ & $7(9.7 \%)$ & $\begin{array}{l}36 \\
(50 \%)\end{array}$ \\
\hline Good & $\begin{array}{l}25 \\
(49.1 \%)\end{array}$ & $\begin{array}{l}16 \\
(31.4 \%)\end{array}$ & $\begin{array}{l}6 \\
(11.8 \%)\end{array}$ & $\begin{array}{l}33 \\
(64.7 \%)\end{array}$ & $\begin{array}{l}23 \\
(31.9 \%)\end{array}$ & $\begin{array}{l}30 \\
(41.7 \%)\end{array}$ & $\begin{array}{l}29 \\
(40.3 \%)\end{array}$ & $\begin{array}{l}25 \\
(34.7 \%)\end{array}$ \\
\hline Enough & $\begin{array}{l}18 \\
(35.3 \%)\end{array}$ & $4(7.8 \%)$ & $\begin{array}{l}23 \\
(45.1 \%)\end{array}$ & $\begin{array}{l}8 \\
(15.7 \%)\end{array}$ & $\begin{array}{l}29 \\
(40.3 \%)\end{array}$ & $\begin{array}{l}18 \\
(25 \%)\end{array}$ & $\begin{array}{l}23 \\
(31.9 \%)\end{array}$ & $\begin{array}{l}11 \\
(15.3 \%)\end{array}$ \\
\hline Under & $5(9.8 \%)$ & $0(0 \%)$ & $\begin{array}{l}20 \\
(39.2 \%)\end{array}$ & $2(3.9 \%)$ & $\begin{array}{l}17 \\
(23.6 \%)\end{array}$ & $1(1.4 \%)$ & $\begin{array}{l}13 \\
(18.1 \%)\end{array}$ & $0(0 \%)$ \\
\hline
\end{tabular}

Activities at SMPN 3 Banjarbaru executed in 5 classes with two different times. This 
activity consists of two materials, namely on adolescent reproductive health and pornography. The number of participants who follow these events amounted to 123 people who come from class VII-A. VII-B, VII-C, VII-E dan VII-F representative. Pre-post test performed in order to measure changes in knowledge, done before the election activities counselor begins, with the division of two different materials, namely on adolescent reproductive health and pornography.

The results of the observation level of knowledge before and after implementation of the activities previously indicated any change there are 57 people $(46.34 \%)$ who have a good knowledge, after participating in the activities has increased to $88(71.54 \%)$ who have a good level of knowledge. Results of follow-up observations to evaluate the knowledge of participants found that an increase in knowledge of $41(33.34 \%)$ who have a good knowledge to 114 people $(92.68 \%)$ who have a good level of knowledge. The results of the statistical analysis found that $\mathrm{p}$-value $=0.000$ which is less than $\alpha=0.05$. It shows that we conclude H0 is rejected, which means that there is a difference in students' knowledge before and after participating in activities concerning adolescent reproductive health and pornography.

\section{Discussion}

Pornography can cause damage to the five parts of the brain, especially in the pre frontal corteks (part of the brain right behind the forehead). This resulted in decreased academic performance, people can not make plans, control the passions and emotions and make decisions. Pornography is one of the problems highlighted the government, especially the Ministry of Communications and Information in Indonesia. Blocking or filter method, and also called on the telecommunications companies and Internet service providers are obliged to block web sites containing pornographic content have been carried out. But these efforts have not overcome the problem of pornography in their entirety.

To address these problems need to be alternatives to the prevention and control through the method performed in community anti-pornography program is the method of peppermint. First, peer educators (peer educators) is a process of communication, information, education and communication (IEC) conducted by and for the peer. Secondly, the delivery of education by peer counselor to the youth with the lecture method is a way of delivering a message that is most common to share knowledge and health facts. This method will be effective when coupled with a question and answer session with the participants, resulting in a two-way communication. The third method, which is Motivational Interviewing (MI) is one of the counseling technique is intended to encourage individuals to explore, and find the reason of her that she had never thought to change its behavior. MI method is suitable to apply to the teenagers who indicated addicted to pornography. With the implementation of this program will form the community that will receive education and training provision of the personal skills of the counselor peppermint order to avoid the behavior of juvenile pornography and increase understanding about the true intent or knowledge of sexual and reproductive health of adolescents and to prevent sexually deviant behavior.

An increase in student knowledge occurs because counseling is carried out not only through media lectures, but through interactive dialogues, media slides, posters and videos and interspersed with ice breaking to overcome boredom during counseling. Video media relies on the hearing and sight of the target, where the use of audiovisual involves all the senses, so that the more senses involved to receive and process information, the more likely the contents of the information can be understood and maintained in memory, and with the effect of moving images 
and sound effects can make it easier for the audience to understand the contents of the news so that they can increase knowledge [13]. Providing education to students is also supported by poster media. The importance of using promotional media is an increase in knowledge, skills, attitudes and behaviors that are the result of the learning process in promotional activities, whose success is determined by the effectiveness of promotional media, and the effectiveness of using promotional media is largely determined by the number of senses used [14].

\section{Conclusion}

The result of this activity indicates that there is an increased knowledge of students before and after the activity. Based on the analysis results obtained p-value $=0.000$ which is less than $\alpha=0.05$. It shows that we conclude $\mathrm{H} 0$ is rejected, which means that there is a difference in students' knowledge before and after participating in activities concerning adolescent reproductive health and pornography. Therefore, it takes more effort to develop community empowerment peppermint counselors and students to prevent and address the problems of pornography and adolescent reproductive health that occurs, monitoring and evaluation of peppermint counselor who became the first pioneers in this activity.

\section{References}

[1] Astuti S D, Idola P P, Dini S F A. Strategi Komunikasi Program Internet Sehat dan Aman Kementerian Komunikasi dan Informatika Republik Indonesia (Studi Kasus Evaluasi Program Incakap Tahun 2015). Jurnal Komunikasi, 2016; 8(1): 25 - 35.

[2] Prasetyo D P, Muarrofah, Dwi P. Pornografi Terhadap Relasi Heteroseksual Remaja SMP Usia 12-15 Tahun. Nursing Journal Of Stikes Insan Cendekia Medika Jombang, 2017; 13(1): 40 - 46.

[3] Azkiyah L. Bibliokonseling virtual: metode pengurangan tindak pikiran pornografi pada siswa SMPN 1 Karangploso. Cendekia, 2017; 11(2): 183-194.

[4] Susanto. Memerangi Pornografi Anak. https://nasional.kompas.com/read/2017/03/23/19013821/memerangi.pornografi.anak. 2017; Diakses 4 Juni 2018.

[5] Khoirul A. Masalah Pornografi Jadi Sorotan Semua Pihak. http://www.nu.or.id/post/read/23413/masalah-pornografi-jadi-sorotan-semua-pihak. 2010; Diakses 23 September 2018.

[6] Ervyna A, Putu ASU, I Wayan S. Pengaruh Peer Education Terhadap Perilaku Personal Hygiene Genetalia Dalam Pencegahan Kanker Serviks Pada Remaja Putri Di SMP Negeri 10 Denpasar. COPING Ners Journal, 2015; 3(2): 61-67.

[7] Krismayanti NLPY, Trisno AW, Nining TSS. Pendidikan Seks Melalui Peer Counselor Terhadap Pengetahuan Remaja Tentang Seks Pranikah. Jurnal Ilmu Kebidanan, 2013; I(2) : 71-77.

[8] Fembi PN. Pengaruh Pendekatan Motivational Interviewing Terhadap Motivasi dan Kemandirian Penderita TB dalam Pengobatan TB Paru. Jurnal Ners, 2013; 8(2) : 217-225.

[9] Nursalim M. Peran Konselor Dalam Mengantisipasi Krisis Moral Anak dan Remaja Melalui Pemanfaatan Media "Baru”. Jurnal Bikotetik, 2017; 01(02) : 37 - 72. 
[10] Ardi Z, Yulidar I, Azrul S. Capaian Tugas Perkembangan Sosial Siswa Dengan Kelompok Teman Sebaya Dan Implikasinya Terhadap Program Pelayanan Bimbingan Dan Konseling. Konselor, 2012; 1(1) : 1-8.

[11] Usman R. Penggunaan Tutor Sebaya Dan Aktivitas Siswa Untuk Meningkatkan Hasil Belajar Pokok Bahasan Analisis Isi Pidato Siswa Kelas Viii SMP Negeri 2 Tapung. GERAM (Gerakan Aktif Menulis), 2017; 5(2): 16-27.

[12] Sinaga D. Pornografi Masih Menjadi Problem yang Membelit Anak. https://student.cnnindonesia.com/keluarga/20170723060320-436-229707/pornografimasih-menjadi-problem-yang-membelit-anak/. 2017; Diakses 4 Juni 2018.

[13] Tindaon RL. Pengaruh komunikasi, informasi, dan edukasi (kie) melalui media leaflet dan video terhadap pengetahuan dan sikap remaja tentang paparan pornografi di SMP Negeri 1 Sidamanik Kec. Sidamanik Kab. Simalungun Tahun 2016. JUMANTIK, 2017; 3(1): 4464.

[14] Evianasari N dan Anggraini. Pengaruh media kie "aku bangga aku tahu" terhadap pengetahuan remaja tentang HIV\&AIDS di SMA "P" Bandar Lampung Tahun 2017. Jurnal Kebidanan, 2017; 3(3): 141-148. 